\title{
Tensile Strain Measurements of Ceramic Fibers Using Scanning Laser Acoustic Microscopy
}

Renee M. Kent

University of Dayton

Dayton, Ohio

and

Alex Vary

Lewis Research Center

Cleveland, Ohio

Prepared for the

16th Annual Conference on Composites and Advanced Ceramics sponsored by the American Ceramic Society

Cocoa Beach, Florida, January 7-10, 1992

\section{N/Sก}


$=$

$+\cdots=$ 


\title{
TENSILE STRAIN MEASUREMENTS OF CERAMIC FIBERS USING
}

\section{SCANNING LASER ACOUSTIC MICROSCOPY}

\author{
Renee M. Kent ${ }^{*}$ \\ University of Dayton \\ Dayton, Ohio 45469 \\ and \\ Alex Vary \\ National Aeronautics and Space Administration \\ Lewis Research Center \\ Cleveland, Ohio 44135
}

\section{SUMMARY}

A noncontacting technique using scanning laser acoustic microscopy for making in situ tensile strain measurements of small diameter fibers was implemented for the tensile strain analysis of individual Nicalon $\mathrm{SiC}$ fibers (nominal diameter $15 \mu \mathrm{m}$ ). Stress versus strain curves for the fibers were plotted from the experimental data. The mean elastic modulus of the fibers was determined to be 185.3 GPa. Similar measurements were made for Carborundum SiC fibers (nominal diameter $28 \mu \mathrm{m}$ ) and Saphikon sapphire fibers (nominal diameter $140 \mu \mathrm{m}$ ), yielding an elastic modulus of 401 and $466.8 \mathrm{GPa}$, respectively.

\section{INTRODUCTION}

Ceramic-ceramic composites have elevated temperature properties which make them attractive candidates for high performance aerospace structural applications. These materials have high specific strengths at elevated temperatures, high thermal stability, resistance to thermal shock and oxidation, and an estimated maximum operating temperature of $3000^{\circ} \mathrm{F}$. In addition, the ceramic reinforcing fibers enhance the composite system's resistance to fracture and catastrophic failure.

Accurate quantitative characterization of the reinforcing fibers is essential for the reliable characterization of composite structures under their operating conditions. However, material property measurements of small diameter fibers are difficult to achieve by traditional methods.

In this work, a noncontacting ultrasonic method using scanning laser acoustic microscopy (SLAM) for measuring tensile strain was applied to selected ceramic fibers. This technique proved to be a convenient and reliable approach that did not alter the mechanical response of the fibers during loading and strain measurement.

\footnotetext{
*NASA Resident Research Associate at Lewis Research Center.
} 


\section{THEORY}

The operation and design of the scanning laser acoustic microscope (SLAM) ${ }^{1}$ has been described in the literature in references 1 and 2. Fundamentally, a piezo-electric transducer transmits an acoustic wave through the ceramic fiber specimen. This wave causes periodic fluctuations within the specimen characteristic of the material structure. A laser beam scanned over the surface of the fiber is modulated as a function of these periodic fluctuations. In essence, the scanning laser beam is used to detect acoustic disturbances in the specimen. This acousto-optical coupling yields a diffraction limited resolution capability of the system, i.e.,

$$
R=1.22 \Lambda f / *
$$

where $\Lambda$ is the acoustic wavelength in the specimen and $f /^{*}$ is the $f$-number of the detection system. This permits the investigation and analysis of materials having small dimensions (to $11 \mu \mathrm{m}$ ).

The SLAM system has been used primarily for defect detection and characterization (refs. 3 and 4). However, by analyzing the acousto-optical signal response from the specimen directly, quantitative material behavior measurements are possible.

The detected acousto-optical signal is added to an electronic phase reference signal to form a series of interference fringes characteristic of the internal structure of the specimen. As the specimen is stressed, the modulation of the scanning laser beam is altered. This is indicated as a shift of the interference fringes which is directly proportional to the magnitude of the strain in the specimen. ${ }^{2}$

\section{EXPERIMENTAL PROCEDURE}

The ceramic fibers studied were Nicalon $\beta$-SiC (15 $\mu \mathrm{m}$ diameter), Saphikon $\alpha-\mathrm{Al}_{2} \mathrm{O}_{3}(140 \mu \mathrm{m}$ diameter), and Carborundum $\alpha$-SiC (28 $\mu \mathrm{m}$ diameter). The individual fiber specimens were epoxied to $0.0254 \mathrm{~mm}$ thick stainless steel shim stock tabs as shown schematically in figure 1 . The tabs were machined to yield a 1-in. gauge length configuration. The tabs were configured such that they could be cut, after the assembly was positioned in the measurement system, for load transfer to the fiber. One end of the tab was secured to the SLAM stage. A calibrated static load was applied to the other end via a frictionless air bearing pulley assembly designed to minimize the losses due to frictional effects between the SLAM stage and the shim tab. The experimental set up is shown in figure 2.

A small drop of water was placed between the piezo-electric transducer and the specimen. The water served as an acoustic couplant which promoted effective acoustic transfer from the piezo-electric crystal to the specimen. The crystal operated at $100 \mathrm{MHz}$ for all experiments described in this work. A mirrored coverslip was placed $0.0254 \mathrm{~mm}$ above the specimen to increase the reflectivity of the diffracted signal. The signal from the SLAM interference fringes at the detector plane was directed to a $100 \mathrm{MHz}$ oscilloscope. The raster line at the location of the fiber was selected and the fringe shift was measured directly from the analog signal on the scope. The fringe shift yielded a measure of the tensile strain on the fiber.

${ }^{1}$ Sonoscan, Inc.

${ }^{2} \mathrm{~A}$ more detailed description of the measurement technique used is presently being prepared for a Ph.D. dissertation at the University of Dayton. 
After the strain measurement was completed, each fiber was removed from the SLAM system. The diameter of each was optically measured by laser diffraction using the United Calibration Corporation measuring system.

The strains for 15 individual Nicalon fibers were measured at three different load levels $(10,15$, and $20 \mathrm{~g}$ ). The data were analyzed using a complete randomized block experimental design. The elastic modulus calculated at each measurement point formed a 3 by 15 experimental matrix. In this design, the fiber to fiber variation was normalized and the residual variance was used to estimate the measurement uncertainty and reliability of the individual measurement. For each fiber, the strain data were plotted on stress (obtained from the measured loads and fiber diameters) versus strain curves and the elastic modulus of the individual fibers was calculated by the method of linear regression. The results obtained were compared with the values reported in the literature.

Saphikon $\alpha-\mathrm{Al}_{2} \mathrm{O}_{3}$ and Carborundum SiC fibers were measured using similar procedures. The stress versus strain curves plotted from the data obtained were used to calculate the elastic modulus of each fiber.

\section{RESULTS AND DISCUSSION}

Figures 3 to 5 present stress versus strain curves for each of the fibers studied. The error bars shown are propagated from the measurement uncertainties. This propagated measurement error is generally less than 5 percent of the absolute strain measurement. For the fifteen Nicalon fibers studied, the mean elastic modulus, calculated from a linear regression of the measured stress and strain, was 185.3 GPa (fig. 3). This compares with a value of $193 \mathrm{GPa}$ reported in the literature in reference 5 (a mean deviation of 2.8 percent).

The elastic modulus of the Saphikon $\mathrm{Al}_{2} \mathrm{O}_{3}$ fiber was calculated from the stress versus strain curves to be $466.8 \mathrm{GPa}$ (fig. 4). This is within 1 percent of the value reported in the literature for c-axis $\alpha$ $\mathrm{Al}_{2} \mathrm{O}_{3}(468.8 \mathrm{GPa}$ ) (ref. 6). The values reported are for c-axis fibers only. In some instances, elastic modulus values as low as $420 \mathrm{GPa}$ were measured. However, further investigations of these fibers showed that they were off-axis by as much as $25^{\circ}$.

The elastic modulus of the Carborundum SiC fibers was determined to be $401 \mathrm{GPa}$ (fig. 5). This value is 4.4 percent below the theoretical elastic modulus for this material (ref. 7). Subsequent analysis of the Carborundum SiC fiber studied showed a high degree of internal porosity, accounting for the low measured elastic modulus (ref. 8). This analysis was confirmed by the manufacturer (ref. 9).

The complete randomized block analysis of the resultant data shows that there is a statistically significant variation in the measured elastic modulus of the Nicalon SiC from fiber to fiber. The standard deviation of the elastic modulus is $22 \mathrm{GPa}$ or approximately 12 percent about the mean. Accurate accounting of these deviations in the modulus is an important step in the material characterization process. In this case, the variance is primarily attributed to subtle differences in the microstructure from fiber to fiber. Figure 6 shows SEM micrographs of two Nicalon fibers which exhibit different textures on their fracture surfaces.

The SLAM measurement technique used in this study can also perform strain measurements on short gauge length (to 0.25 in.) specimens. This suggests potential success for measurement of the in situ tensile strain and elastic modulus of ceramic whiskers as well as measurement of local in situ strain distributions in larger specimens. 


\section{CONCLUSIONS}

This work describes the results of measuring the tensile strain and elastic modulus of small diameter ceramic fibers using scanning laser acoustic microscopy (SLAM). An analysis of these properties for three different ceramic fibers is presented. The size and brittle nature of these fibers has previously prevented an accurate assessment of these properties. The SLAM measurement technique used allows analysis of material specimens having small dimensions and short gauge lengths.

\section{ACKNOWLEDGMENTS}

The authors are grateful to Greg Selover and Pat Book from the NASA Lewis Research Center who prepared the specimens for testing and performed the SEM work. Appreciation also goes to Dr. Norman Hecht from the University of Dayton Research Institute for his helpful suggestions.

\section{REFERENCES}

1. Whitman, R.L.; and Korpel, A.: Probing of Acoustic Surface Perturbations by Coherent Light. Appl. Opt., vol. 8, no. 8, 1969, pp. 1567-1576.

2. Korpel, A.; and Desmarces, P.: Rapid Sampling of Acoustic Holograms by Laser-Scanning Techniques. J. Acoust. Soc. Am., vol. 45, no. 4, 1969, pp. 881-884.

3. Kessler, L.W.; and Yuhas, D.E.: Acoustic Microscopy-1979. Proc. IEEE, vol. 67, no. 4, 1979, pp. 526-536.

4. Roth, D.J., et al.: Reliability of Void Detection in Structural Ceramics by Use of Scanning Laser Acoustic Microscopy. Mater. Eval., vol. 44, no. 6, May 1986, pp. 761-769.

5. DOW Corning Nicalon Ceramic Fiber Specifications Data Sheet. Dow Corning, Midland, MI, 1989.

6. Wachtman, J.B. Jr., et al.: Elastic Constants of Synthetic Single Crystal Corundum at Room Temperature. Nat. Bur. Stand. J. Res., vol. 64A, no. 3, May-June 1960, pp. 213-228.

7. Seshadri, S.G.; Srinivasan, M.; and Chia, K.Y.: Microstructure and Mechanical Properties of Pressureless Sintered Alpha SiC. Silicon Carbide '87: Proceedings of the Symposium, J.D. Cawley and C.E. Semler, eds., American Ceramic Society, Westerville, OH, 1989, pp. 215-226.

8. Rice, R.W.: Microstructure Dependence of Mechanical Behavior of Ceramics. Properties of Microstructure (Treatise on Materials Science and Technology, vol. 11), R.K. MacCrone, ed., Academic Press, 1977, pp. 199-381.

9. Storm, R.S.: Private communication. 


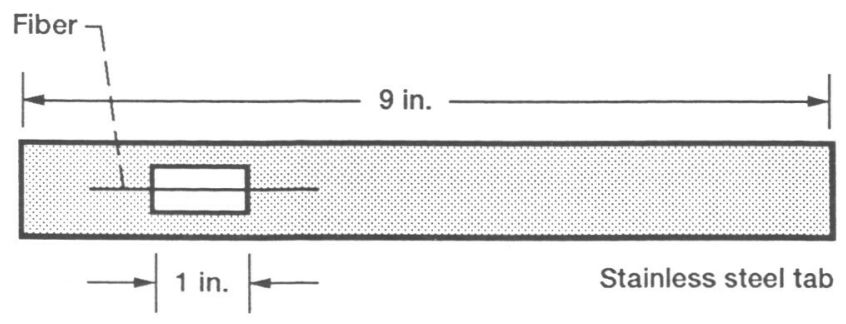

Figure 1.-Fiber specimen configuration.

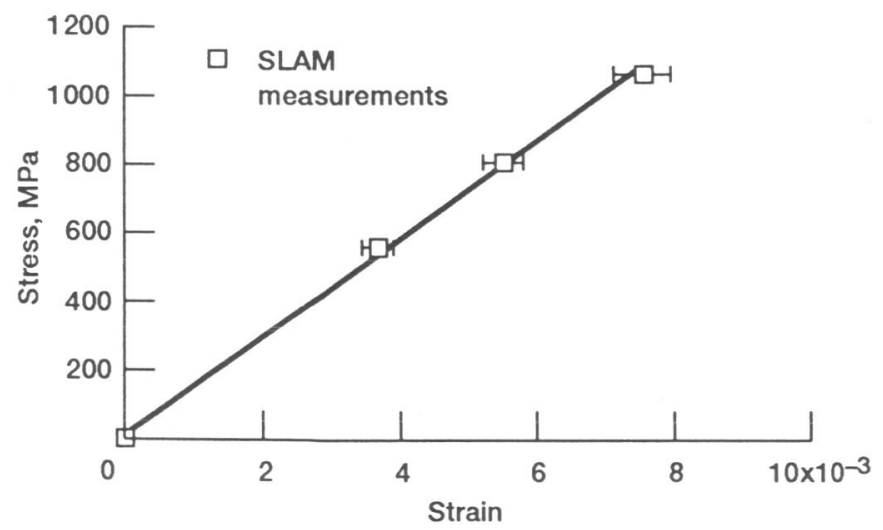

Figure 3.-Stress vs. strain for $15 \mu \mathrm{m}$ Nicalon $\beta$-SiC fiber.

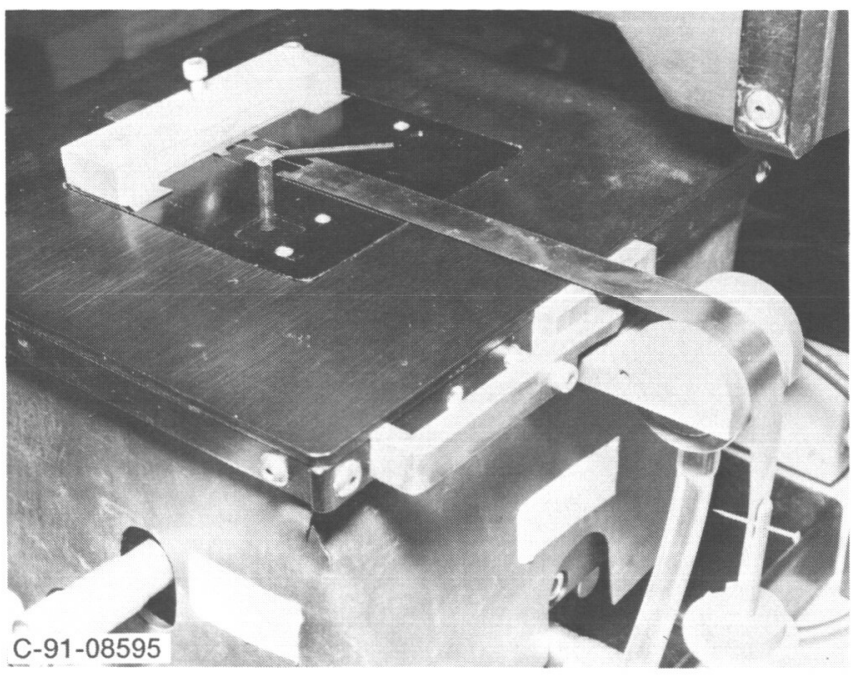

Figure 2.-Configuration for fiber strain measurement.

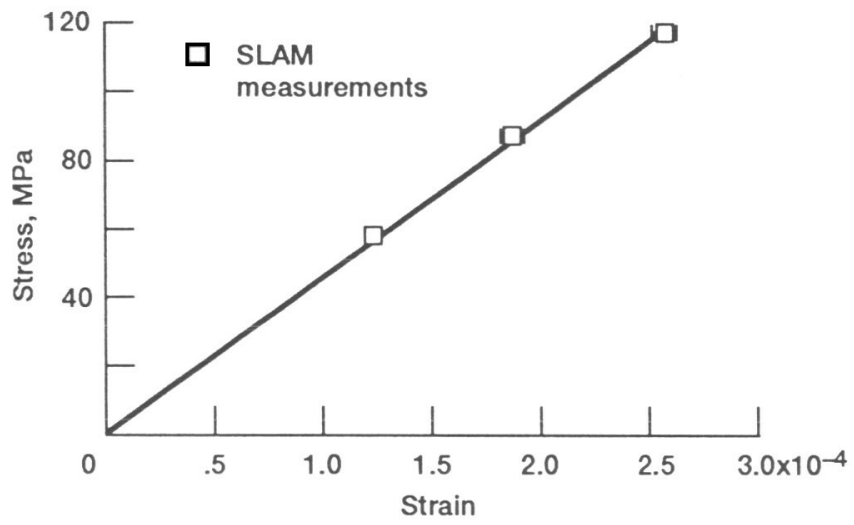

Figure 4.-Stress vs. strain for Saphikon $\alpha-\mathrm{Al}_{2} \mathrm{O}_{3}$ fiber.

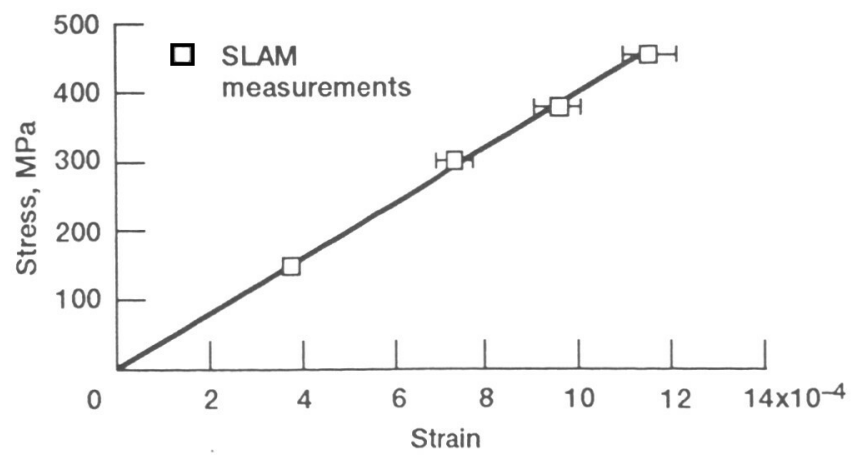

Figure 5.-Stress vs. strain for Carborundum $\alpha-S i C$ fiber. 
ORIGINAL PAGE

BLACK AND WHTE PHOTOGRAPH
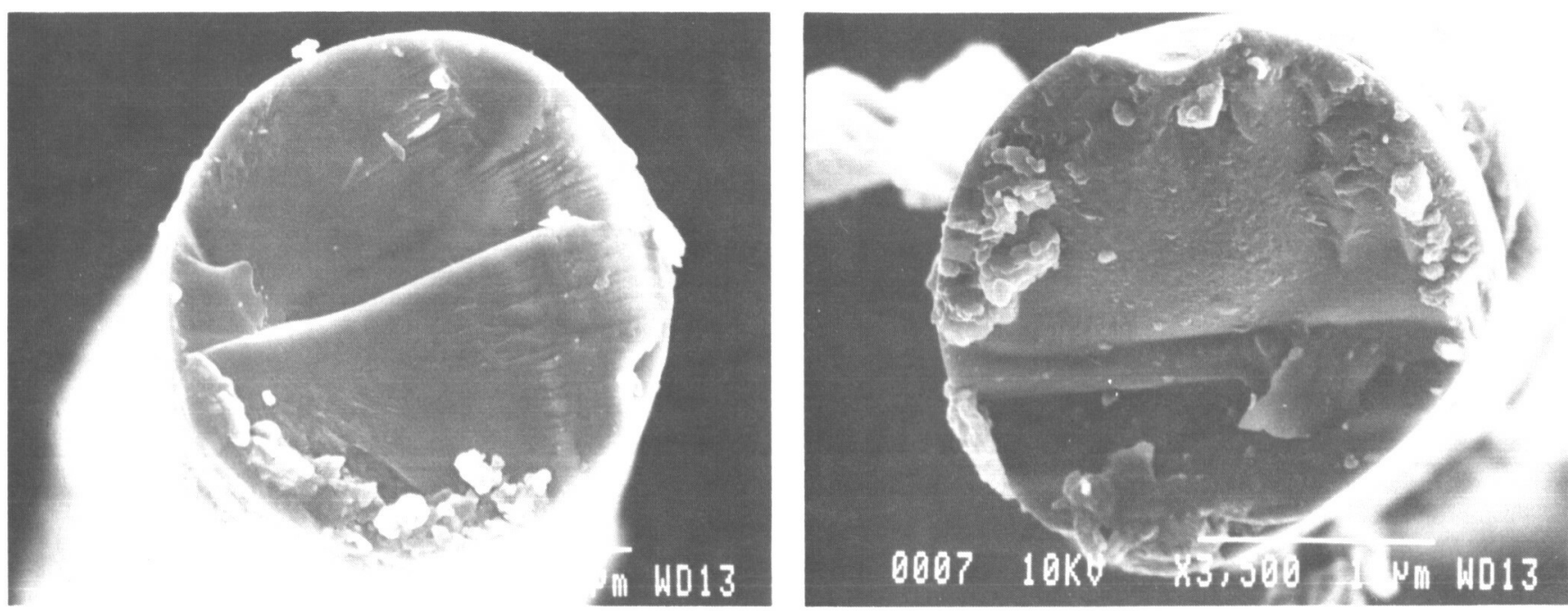

Figure 6.-SEM micrographs of Nicalon SiC fibers. 


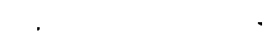




\begin{tabular}{|c|c|c|}
\hline \multicolumn{2}{|c|}{ REPORT DOCUMENTATION PAGE } & $\begin{array}{l}\text { Form Approved } \\
\text { OMB No. 0704-0188 }\end{array}$ \\
\hline \multicolumn{3}{|c|}{ 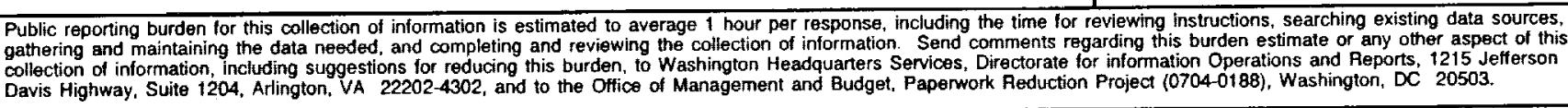 } \\
\hline 1. AGENCY USE ONLY (Leave blank) & $\begin{array}{r}\text { 2. REPORT DATE } \\
1992\end{array}$ & 3. REPORT TYPE AND DATES COVERED \\
\hline $\begin{array}{l}\text { 4. TITLE AND SUBTITLE } \\
\text { Tensile Strain Measurements } \\
\text { Laser Acoustic Microscopy }\end{array}$ & Ceramic Fibers Using Scanning & 5. FUNDING NUMBERS \\
\hline $\begin{array}{l}\text { 6. AUTHOR(S) } \\
\text { Renee M. Kent and Alex Var }\end{array}$ & & WU-510-01-50 \\
\hline $\begin{array}{l}\text { 7. PERFORMING ORGANIZATION NA } \\
\text { National Aeronautics and Sp } \\
\text { Lewis Research Center } \\
\text { Cleveland, Ohio } 44135-319\end{array}$ & $\begin{array}{l}\text { S) AND ADDRESS(ES) } \\
\text { Administration }\end{array}$ & $\begin{array}{l}\text { 8. PERFORMING ORGANIZATION } \\
\text { REPORT NUMBER } \\
\text { E- } 6919\end{array}$ \\
\hline $\begin{array}{l}\text { 9. SPONSORING/MONITORING AGEN } \\
\text { National Aeronautics and Sp } \\
\text { Washington, D.C. } 20546-0\end{array}$ & $\begin{array}{l}\text { NAMES(S) AND ADDRESS(ES) } \\
\text { Administration }\end{array}$ & $\begin{array}{l}\text { 10. SPONSORING/MONITORING } \\
\text { AGENCY REPORT NUMBER } \\
\text { NASA TM - } 105589\end{array}$ \\
\hline \multicolumn{3}{|c|}{$\begin{array}{l}\text { 11. SUPPLEMENTARY NOTES } \\
\text { Prepared for the } 16 \text { th Annual Conference on Composites and Advanced Ceramics sponsored by the American Ceramic Society, Cocoa } \\
\text { Beach, Florida, January 7-10, 1992. Renee M. Kent, University of Dayton, Dayton, Ohio } 45469 \text { and NASA Resident Research Associate } \\
\text { at Lewis Research Center; Alex Vary, NASA Lewis Research Center. Responsible person, Alex Vary, (216) 433-6019. }\end{array}$} \\
\hline $\begin{array}{l}\text { 12a. DISTRIBUTION/AVAILABILITY ST } \\
\text { Unclassified - Unlimited } \\
\text { Subject Category } 38\end{array}$ & EMENT & 12b. DISTRIBUTION CODE \\
\hline
\end{tabular}

\section{ABSTRACT (Maximum 200 words)}

A noncontacting technique using scanning laser acoustic microscopy for making in situ tensile strain measurements of small diameter fibers was implemented for the tensile strain analysis of individual Nicalon SiC fibers (nominal diameter $15 \mu \mathrm{m}$ ). Stress versus strain curves for the fibers were plotted from the experimental data. The mean elastic modulus of the fibers was determined to be $185.3 \mathrm{GPa}$. Similar measurements were made for Carborundum SiC fibers (nominal diameter $28 \mu \mathrm{m}$ ) and Saphikon sapphire fibers (nominal diameter $140 \mu \mathrm{m}$ ), yielding an elastic modulus of 401 and $466.8 \mathrm{GPa}$, respectively.

\begin{tabular}{|c|c|c|c|}
\hline \multirow{2}{*}{\multicolumn{3}{|c|}{$\begin{array}{l}\text { 14. SUBJECT TERMS } \\
\text { Fibers; Strain; Nondestructive testing }\end{array}$}} & \multirow{2}{*}{$\begin{array}{l}\text { 15. NUMBER OF PAGES } \\
8 \\
\text { 16. PRICE CODE } \\
\text { A02 } \\
\text { 20. LIMITATION OF ABSTRACT }\end{array}$} \\
\hline & & & \\
\hline $\begin{array}{l}\text { 17. SECURITY CLASSIFICATION } \\
\text { OF REPORT } \\
\text { Unclassified }\end{array}$ & $\begin{array}{l}\text { 18. SECURITY CLASSIFICATION } \\
\text { OF THIS PAGE } \\
\text { Unclassified }\end{array}$ & $\begin{array}{l}\text { 19. SECURITY CLASSIFICATION } \\
\text { OF ABSTRACT } \\
\text { Unclassified }\end{array}$ & \\
\hline $7540-01-280-5500$ & & & $\begin{array}{l}\text { dard Form } 298 \text { (Rev. 2-89) } \\
\text { cribed by ANSI Std. Z39-18 } \\
102\end{array}$ \\
\hline
\end{tabular}

